\title{
Rotaxanes with Fluorocarbon Blocking Groups
}

Eric J. Mahan^ and Jennifer A. Dennis

SUPPORTING INFORMATION

Pages

Experimental Procedures and Characterization Data for Compounds

2, 3-2PF $6,4-2 P_{6}$, and 5-2PF

${ }^{1} \mathrm{H}$ and ${ }^{13} \mathrm{C}$ NMR spectra for compound 2

${ }^{1} \mathrm{H}$ and ${ }^{13} \mathrm{C}$ NMR spectra for compound $\mathbf{3 - 2} \mathbf{P F}_{\mathbf{6}}$

${ }^{1} \mathrm{H}$ and ${ }^{13} \mathrm{C}$ NMR spectra for compound 4-2PF 6

${ }^{1} \mathrm{H}$ and ${ }^{13} \mathrm{C}$ NMR spectra for compound $\mathbf{5 - 2} \mathbf{P F}_{\mathbf{6}}$

Mass spectrum for compound $\mathbf{5 - 2} \mathbf{P F}_{\mathbf{6}}$

${ }^{1} \mathrm{H}$ spectrum for compound 4-2PF 6 and DB24C8

S13

Mass spectrum for compound $\mathbf{4 - 2 P F}_{\mathbf{6}}$ and $\mathbf{D B 2 4 C 8}$

S14

${ }^{1} \mathrm{H}$ spectrum for compound $\mathbf{3 - 2 P F}_{6}$ and DB24C8

S15

Mass spectrum for compound 3-2PF 6 and DB24C8

S16 
3(4-pyridine)-1-propanol trimethyl silyl ether (2): 3(4-pyridine)-1-propanol (24.6 g, $0.179 \mathrm{~mol})$ was dissolved in THF $\left(400 \mathrm{~mL}\right.$, dried over $\left.\mathrm{MgSO}_{4}\right)$. After the addition of triethylamine (23.8 g, $0.235 \mathrm{~mol})$, chlorotrimethylsilane $(21.4 \mathrm{~g}, 0.197 \mathrm{~mol})$ was added, producing a copious amount of white precipitate. This mixture was stirred for 22 hours, after which time the precipitate was removed by vacuum filtration. The filtrate was concentrated by rotary evaporation, taken up in ether $(500 \mathrm{~mL})$, and extracted with water $(2 \times 75 \mathrm{~mL})$. The organic layer was dried $\left(\mathrm{MgSO}_{4}\right)$ and evaporated to yield a golden yellow oil (29.3 g, 78\%). ${ }^{1} \mathrm{H}$ NMR (200 MHz, $\left.\mathrm{CD}_{3} \mathrm{COCD}_{3}\right): \delta=1.74(\mathrm{~m}, 2 \mathrm{H}), 2.61(\mathrm{t}, \mathrm{J}=$ $6 \mathrm{~Hz}, 2 \mathrm{H}), 3.54(\mathrm{t}, \mathrm{J}=6 \mathrm{~Hz}, 2 \mathrm{H}), 7.12(\mathrm{~d}, \mathrm{~J}=6 \mathrm{~Hz}, 2 \mathrm{H}), 8.37(\mathrm{~d}, \mathrm{~J}=6 \mathrm{~Hz}, 2 \mathrm{H}) ;{ }^{13} \mathrm{C} \mathrm{NMR}$ $\left(200 \mathrm{MHz}, \mathrm{CD}_{3} \mathrm{COCD}_{3}\right): \delta=0.0,32.4,34.4,62.5,125.1,150.9,152.2$; Calcd. For $\mathrm{C}_{11} \mathrm{H}_{19}$ NOSi: C, 63.10; H, 9.15; N, 6.69. Found: $\mathrm{C}, 62.94 ; \mathrm{H}, 9.24 ; \mathrm{N}, 6.81$.

3-2PF 6 : The TMS protected compound $2(29.3 \mathrm{~g}, 140 \mathrm{mmol})$ was dissolved in $\mathrm{CH}_{3} \mathrm{CN}$ (125 mL, dried over $\mathrm{MgSO}_{4}$ ). 1,2-dibromoethane (4.80 g, $25.5 \mathrm{mmol}$ ) was added and the reaction mixture was heated at $40{ }^{\circ} \mathrm{C}$ for 5 days. The brown solid that had formed was filtered by gravity and washed with small portions of $\mathrm{CH}_{3} \mathrm{CN}$. This material was then dissolved in $\mathrm{H}_{2} \mathrm{O}(10 \mathrm{~mL})$ and precipitated from an aqueous solution of $\mathrm{NH}_{4} \mathrm{PF}_{6}(25 \mathrm{~mL})$. The precipitate was filtered by gravity, washed with $\mathrm{H}_{2} \mathrm{O}$, and then dissolved in a minimal amount of $\mathrm{CH}_{3} \mathrm{CN}$. This solution was dried $\left(\mathrm{MgSO}_{4}\right)$ and evaporated to yield the product as a brown solid (4.35 g, 29\%). ${ }^{1} \mathrm{H}$ NMR $\left(200 \mathrm{MHz}, \mathrm{CD}_{3} \mathrm{CN}\right): \delta=1.88(\mathrm{~m}$, 4H), 2.79 (br s, 2H, OH), 2.99 (t, J = $8 \mathrm{~Hz}, 4 \mathrm{H}$ ), 3.54 (t, J = 8 Hz, 4H), 4.95 (s, 4H), 7.89 $(\mathrm{d}, \mathrm{J}=6 \mathrm{~Hz}, 4 \mathrm{H}), 8.39$ (d, J $=6 \mathrm{~Hz}, 4 \mathrm{H}) ;{ }^{13} \mathrm{C} \mathrm{NMR}\left(200 \mathrm{MHz}, \mathrm{CD}_{3} \mathrm{CN}\right): \delta=33.19$, 33.23, 60.6, 61.1, 129.8, 145.3, 166.6; Calcd. For $\mathrm{C}_{18} \mathrm{H}_{26} \mathrm{~N}_{2} \mathrm{O}_{2} \mathrm{P}_{2} \mathrm{~F}_{12}$ : C, 36.50; H, 4.42; N, 4.73; F 38.49. Found: C, 36.41; H, 4.23; N, 4.74; F, 38.72.

4-2PF $\mathbf{6}$ : A solution of $\mathbf{3 - 2} \mathbf{P F}_{\mathbf{6}}(0.349 \mathrm{~g}, 0.589 \mathrm{mmol})$ in $\mathrm{CH}_{3} \mathrm{CN}(20 \mathrm{~mL}$, dried over $\left.\mathrm{MgSO}_{4}\right)$ was dried $\left(\mathrm{MgSO}_{4}\right)$ and filtered by gravity. The filtrate was placed in a flask that was purged with nitrogen. Triethylamine $(0.151 \mathrm{~g}, 1.49 \mathrm{mmol})$ was added via syringe followed by heptafluorobutyryl chloride $(0.622 \mathrm{~g}, 2.68 \mathrm{mmol})$. The resulting solution was stirred at room temperature overnight. The solvent was removed in vacuo to yield a yellow solid that was treated with $\mathrm{CH}_{2} \mathrm{Cl}_{2}$. The undissolved product was removed by gravity filtration and washed with small portions of additional $\mathrm{CH}_{2} \mathrm{Cl}_{2}$. This material was then dissolved in $\mathrm{CH}_{3} \mathrm{CN}(5 \mathrm{~mL})$ and precipitated from an aqueous solution of $\mathrm{NH}_{4} \mathrm{PF}_{6}(25 \mathrm{~mL})$. The precipitate was filtered by gravity, washed with $\mathrm{H}_{2} \mathrm{O}$, and then dissolved in a minimal amount of $\mathrm{CH}_{3} \mathrm{CN}$. This solution was dried $\left(\mathrm{MgSO}_{4}\right)$ and evaporated to yield the product $(0.33 \mathrm{~g}, 57 \%) .{ }^{1} \mathrm{H}$ NMR $\left(200 \mathrm{MHz}, \mathrm{CD}_{3} \mathrm{CN}\right): \delta=2.17$ $(\mathrm{m}, 4 \mathrm{H}), 3.03(\mathrm{t}, \mathrm{J}=8 \mathrm{~Hz}, 4 \mathrm{H}), 4.47(\mathrm{t}, \mathrm{J}=6 \mathrm{~Hz}, 4 \mathrm{H}), 4.97(\mathrm{~s}, 4 \mathrm{H}), 7.91(\mathrm{~d}, \mathrm{~J}=8 \mathrm{~Hz}$, $4 \mathrm{H}), 8.45(\mathrm{~d}, \mathrm{~J}=8 \mathrm{~Hz}, 4 \mathrm{H})$; Calcd. For $\mathrm{C}_{26} \mathrm{H}_{24} \mathrm{~N}_{2} \mathrm{O}_{4} \mathrm{P}_{2} \mathrm{~F}_{26}: \mathrm{C}, 31.72 ; \mathrm{H}, 2.46 ; \mathrm{N}, 2.85 ; \mathrm{F}$ 50.18. Found: C, 31.37; H, 2.39; N, 2.76; F, 49.88.

5-2PF $\mathbf{6}$ : A solution of $\mathbf{3 - 2} \mathbf{P F}_{\mathbf{6}}(0.350 \mathrm{~g}, 0.591 \mathrm{mmol})$ and DB24C8 $(0.265 \mathrm{~g}, 0.591$ $\mathrm{mmol})$ in $\mathrm{CH}_{3} \mathrm{CN}\left(50 \mathrm{~mL}\right.$, dried over $\left.\mathrm{MgSO}_{4}\right)$ was dried $\left(\mathrm{MgSO}_{4}\right)$ and filtered by gravity. The filtrate was placed in a flask that was purged with nitrogen and cooled in an ice bath. Triethylamine $(0.151 \mathrm{~g}, 1.49 \mathrm{mmol})$ was added via syringe followed by heptafluorobutyryl chloride $(0.622 \mathrm{~g}, 2.68 \mathrm{mmol})$. The resulting solution was stirred at 
room temperature overnight. The solvent was removed in vacuo to yield a yellow solid that was treated with $\mathrm{CH}_{2} \mathrm{Cl}_{2}$. After the undissolved side product (4-2PF $)$ was removed by gravity filtration, the filtrate was evaporated to yield a viscous orange oil, which was triturated with ether $(50 \mathrm{~mL})$. The resulting solid was isolated by gravity filtration and then dissolved in hot DMSO (10 $\mathrm{mL}$, dried over $\left.\mathrm{MgSO}_{4}\right)$. The rotaxane product was then precipitated from a hot aqueous solution of $\mathrm{NH}_{4} \mathrm{PF}_{6}(40 \mathrm{~mL})$ and isolated by gravity filtration. After trituration with toluene, the undissolved product was taken up in $\mathrm{CH}_{3} \mathrm{CN}$ and dried over $\mathrm{MgSO}_{4}$. Evaporation of the solvent in vacuo yielded the solid rotaxane product $(272 \mathrm{mg}, 16 \%) .{ }^{1} \mathrm{H}$ NMR $\left(200 \mathrm{MHz}, \mathrm{CD}_{3} \mathrm{CN}\right): \delta=1.86(\mathrm{~m}, 4 \mathrm{H}), 2.59(\mathrm{t}, \mathrm{J}=8$ $\mathrm{Hz}, 4 \mathrm{H}), 3.90(\mathrm{~m}, 8 \mathrm{H}), 3.93$ (m, 8H), 3.98 (m, 8H), 4.37 (t, J = $6 \mathrm{~Hz}, 4 \mathrm{H}), 5.37(\mathrm{~s}, 4 \mathrm{H})$, $6.72(\mathrm{~m}, 8 \mathrm{H}), 7.50(\mathrm{~d}, \mathrm{~J}=6 \mathrm{~Hz}, 4 \mathrm{H}), 8.91(\mathrm{~d}, \mathrm{~J}=6 \mathrm{~Hz}, 4 \mathrm{H})$; Calcd. For $\mathrm{C}_{50} \mathrm{H}_{56} \mathrm{~N}_{2} \mathrm{O}_{12} \mathrm{P}_{2} \mathrm{~F}_{26}: \mathrm{C}, 41.91 ; \mathrm{H}, 3.94 ; \mathrm{N}, 1.96 ; \mathrm{F} 34.47$. Found: $\mathrm{C}, 41.97 ; \mathrm{H}, 3.65 ; \mathrm{N}$, $1.94 ; \mathrm{F}, 34.17$. 


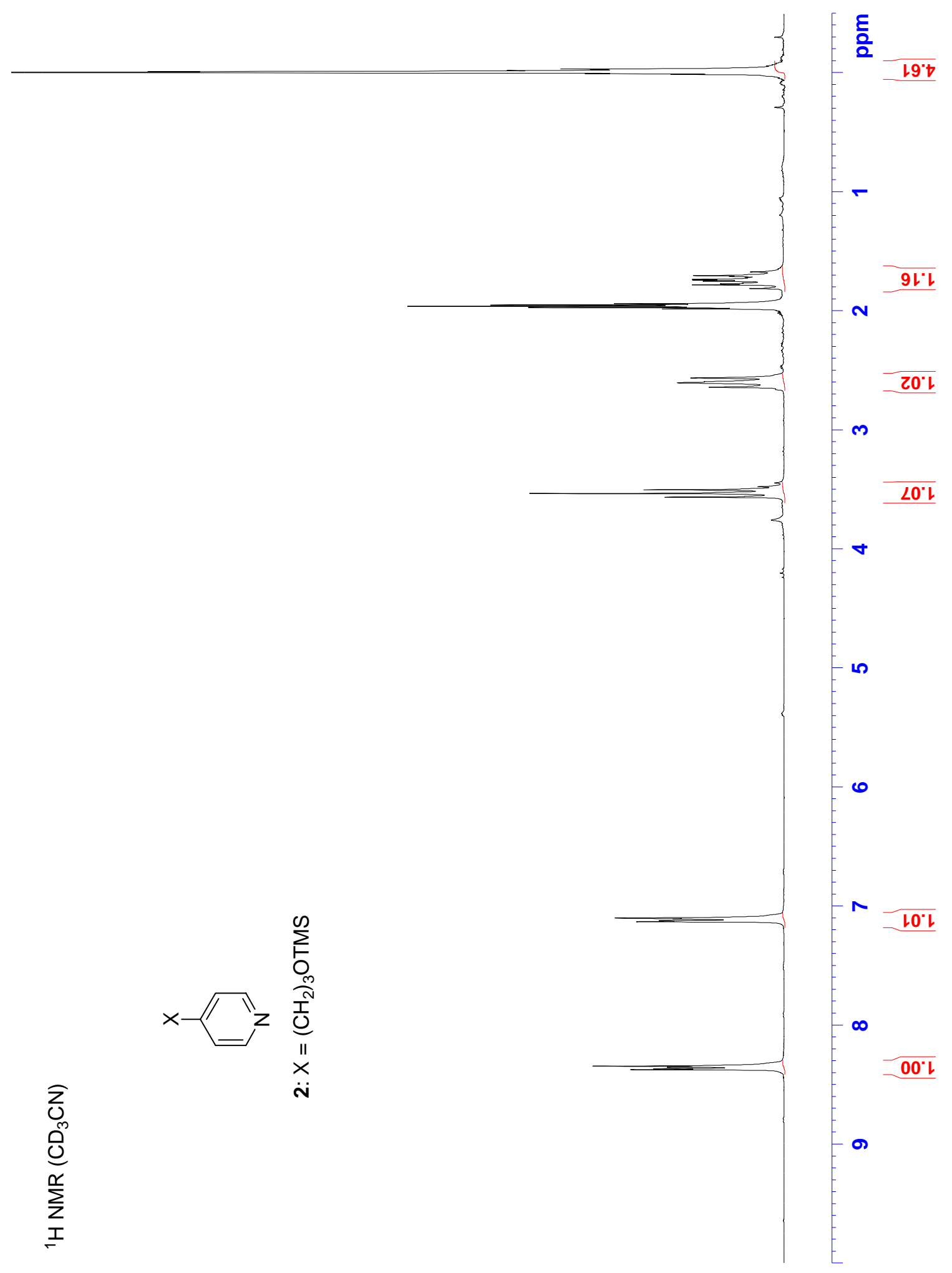



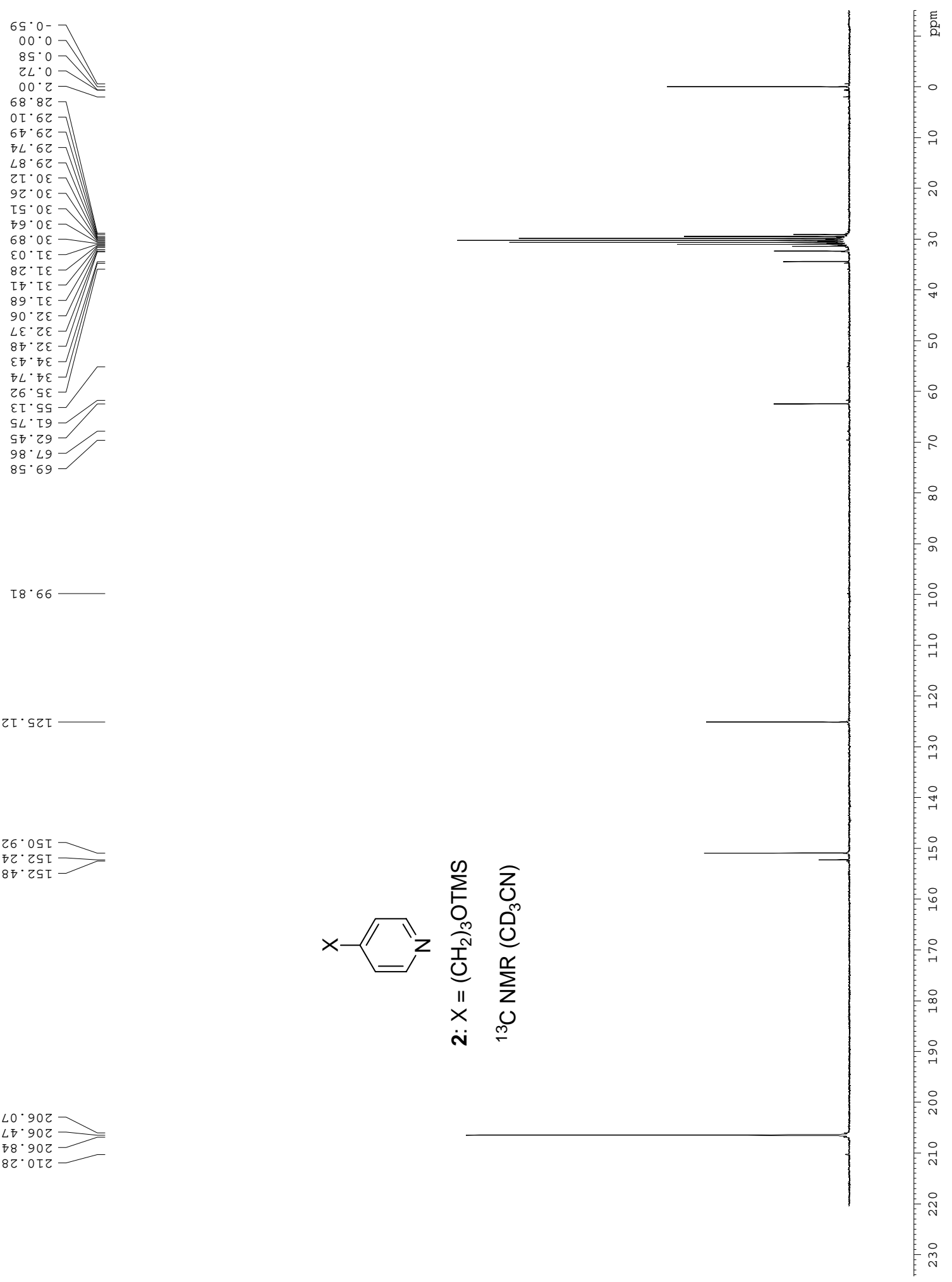


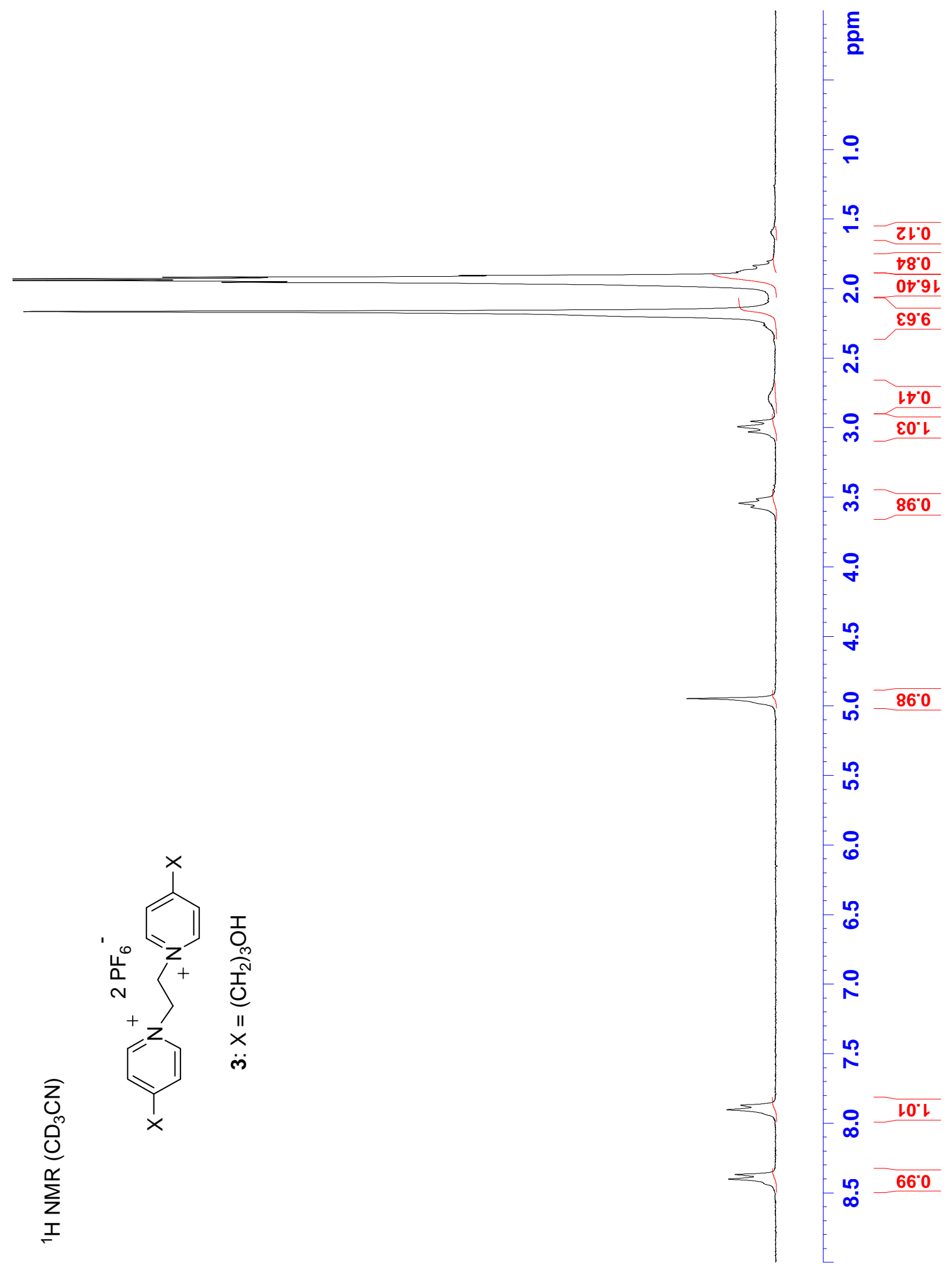




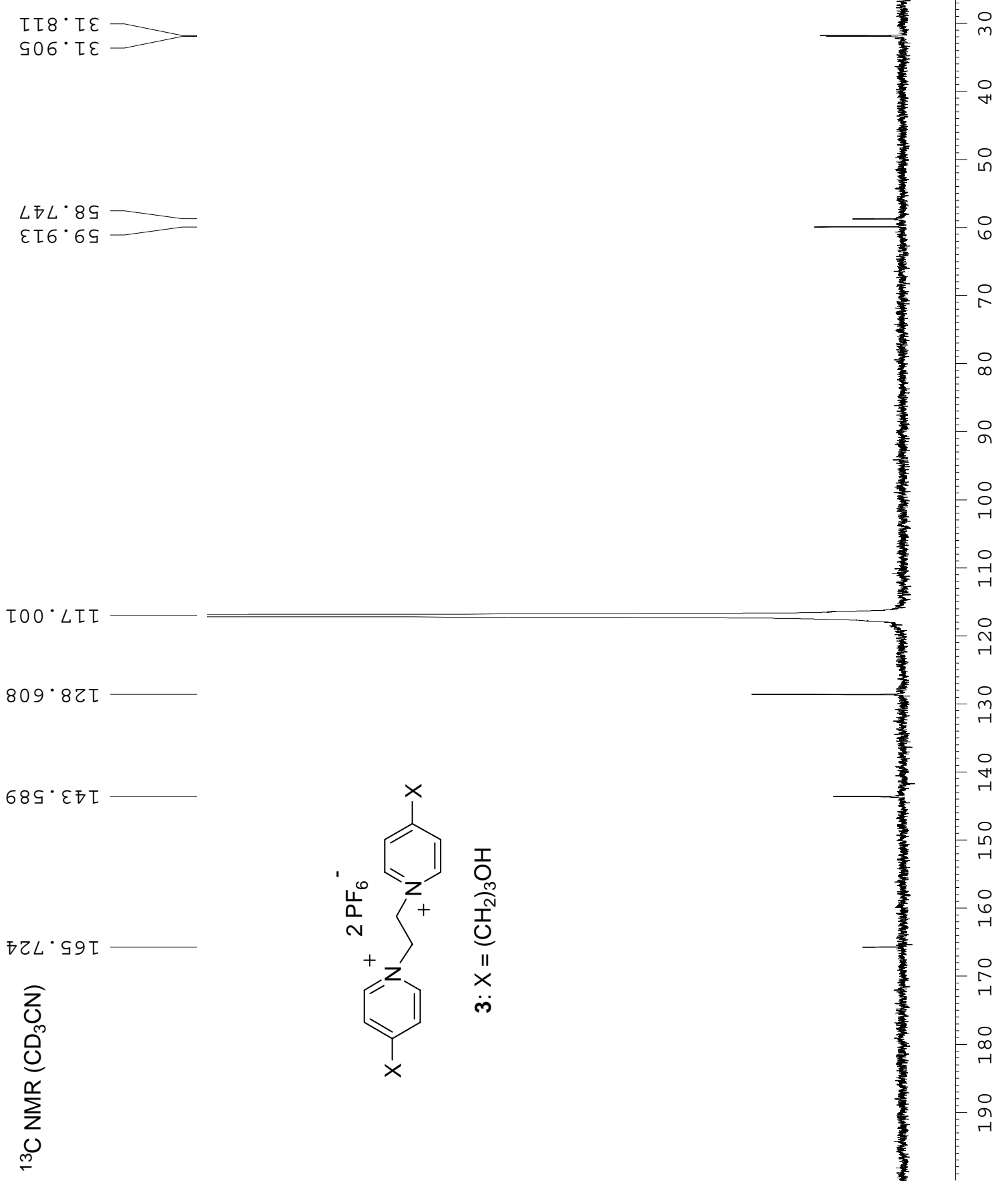




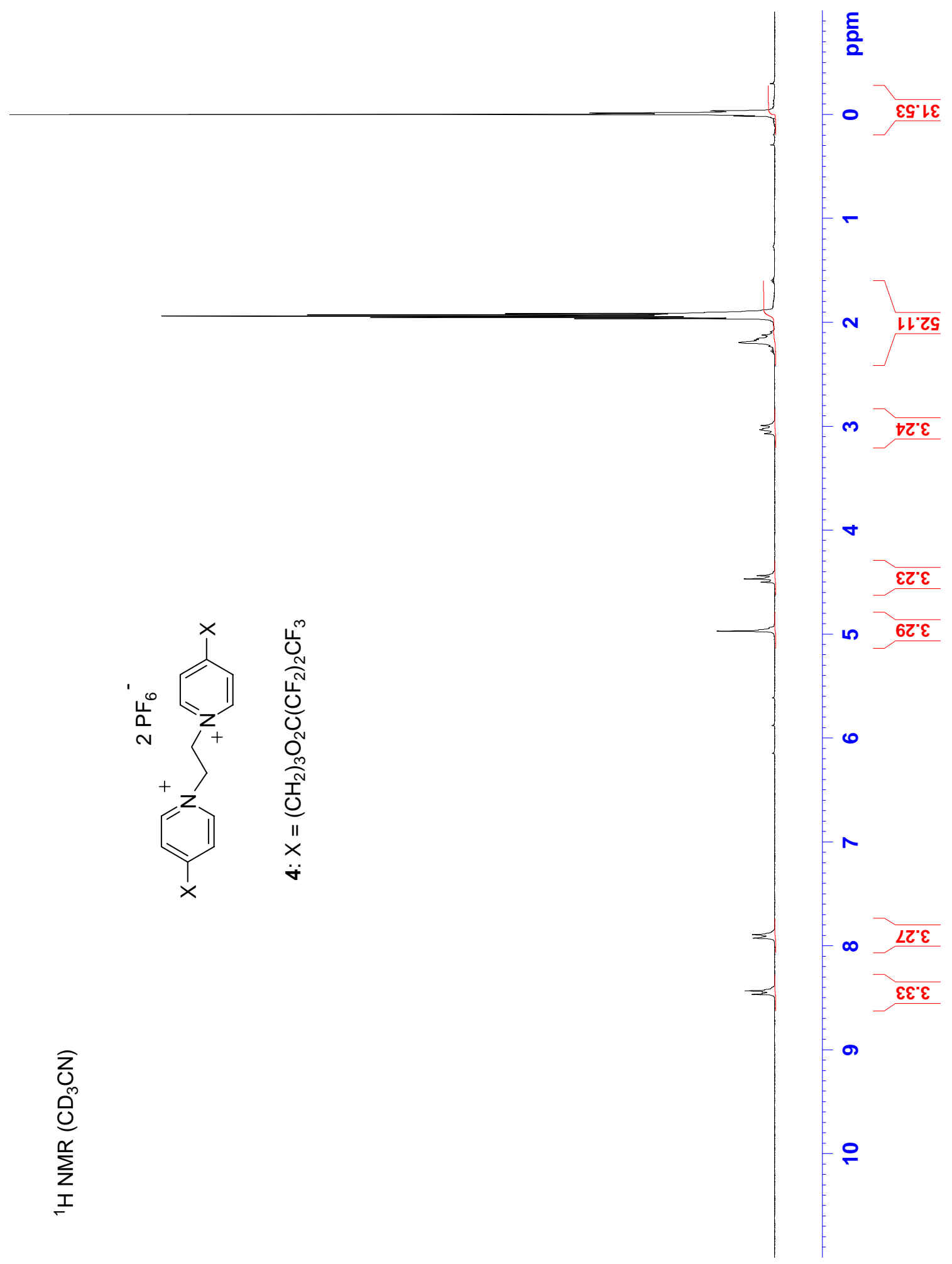




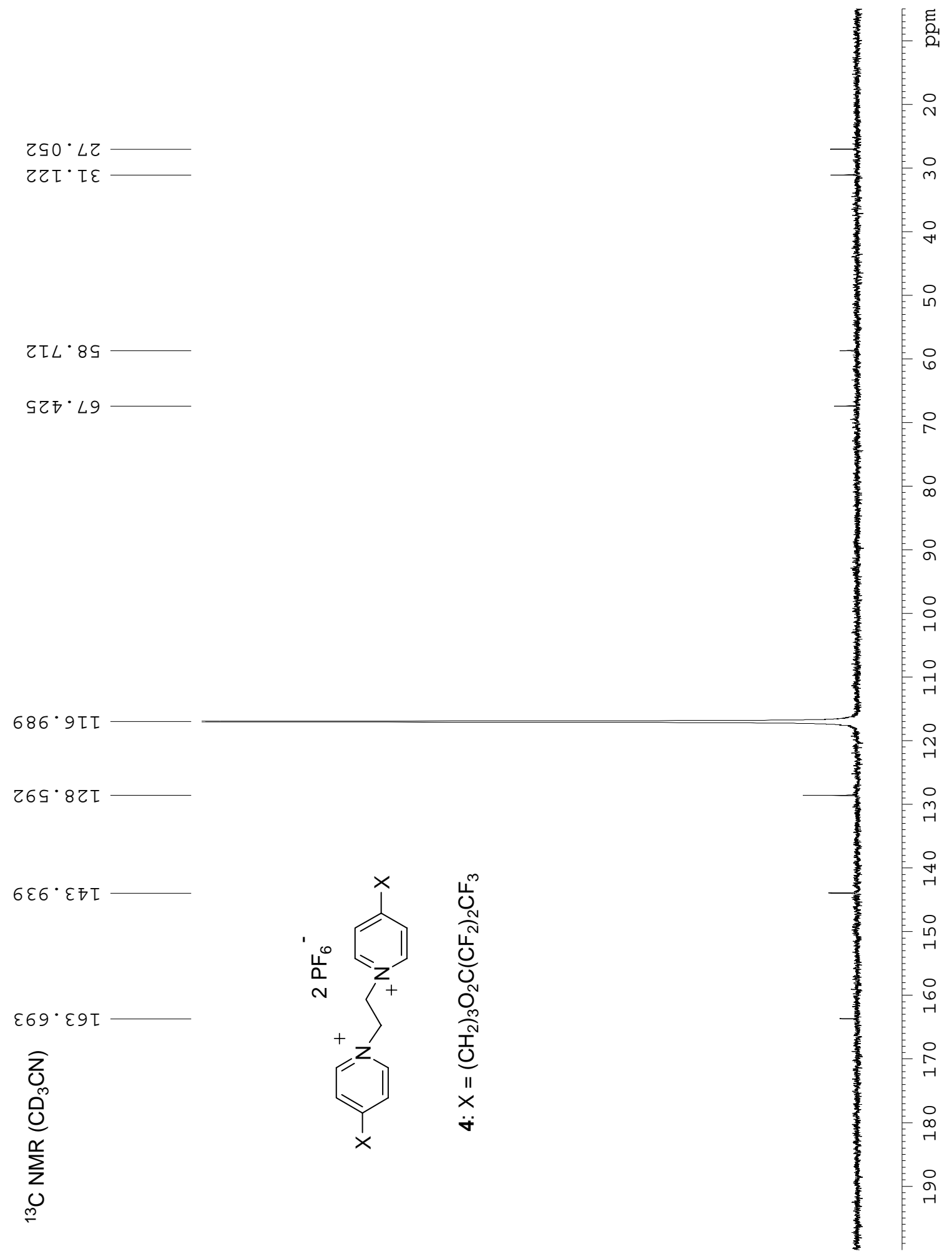




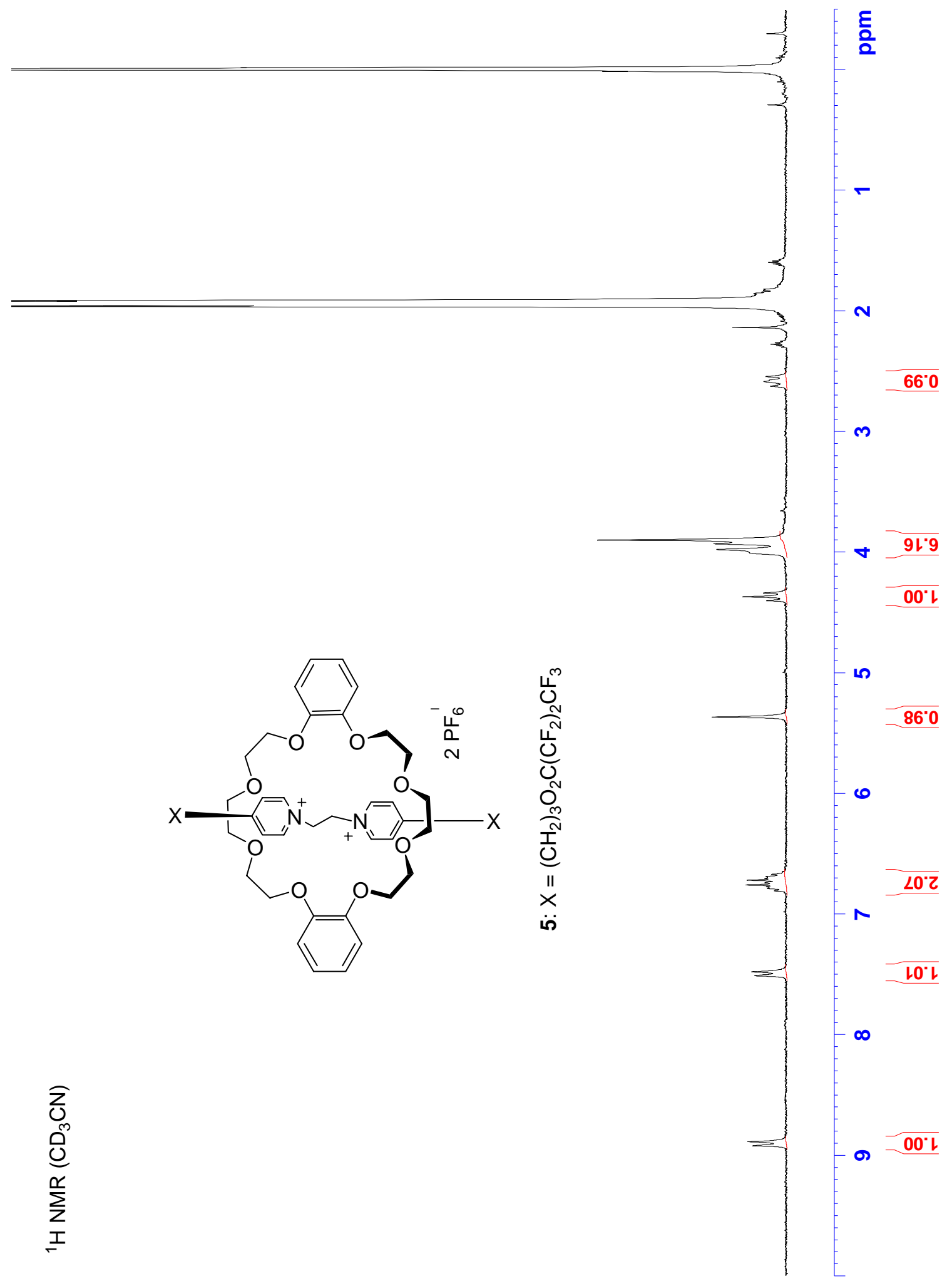


$\varepsilon 乙 L \cdot 9 Z$
$\nabla \varsigma 9 \cdot 0 \varepsilon$

$0 乙 \varepsilon \cdot L S$

$907 \cdot \angle 9$

$9[8 \cdot 69$

$\varepsilon[\varepsilon \cdot 0\llcorner$

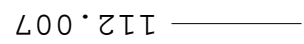

与L6.9โน

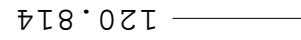

५8 9 '

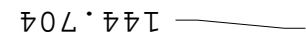

与89.97

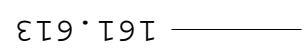

$\sum_{0}$
0
0
$\sum_{0}^{0}$
0
0
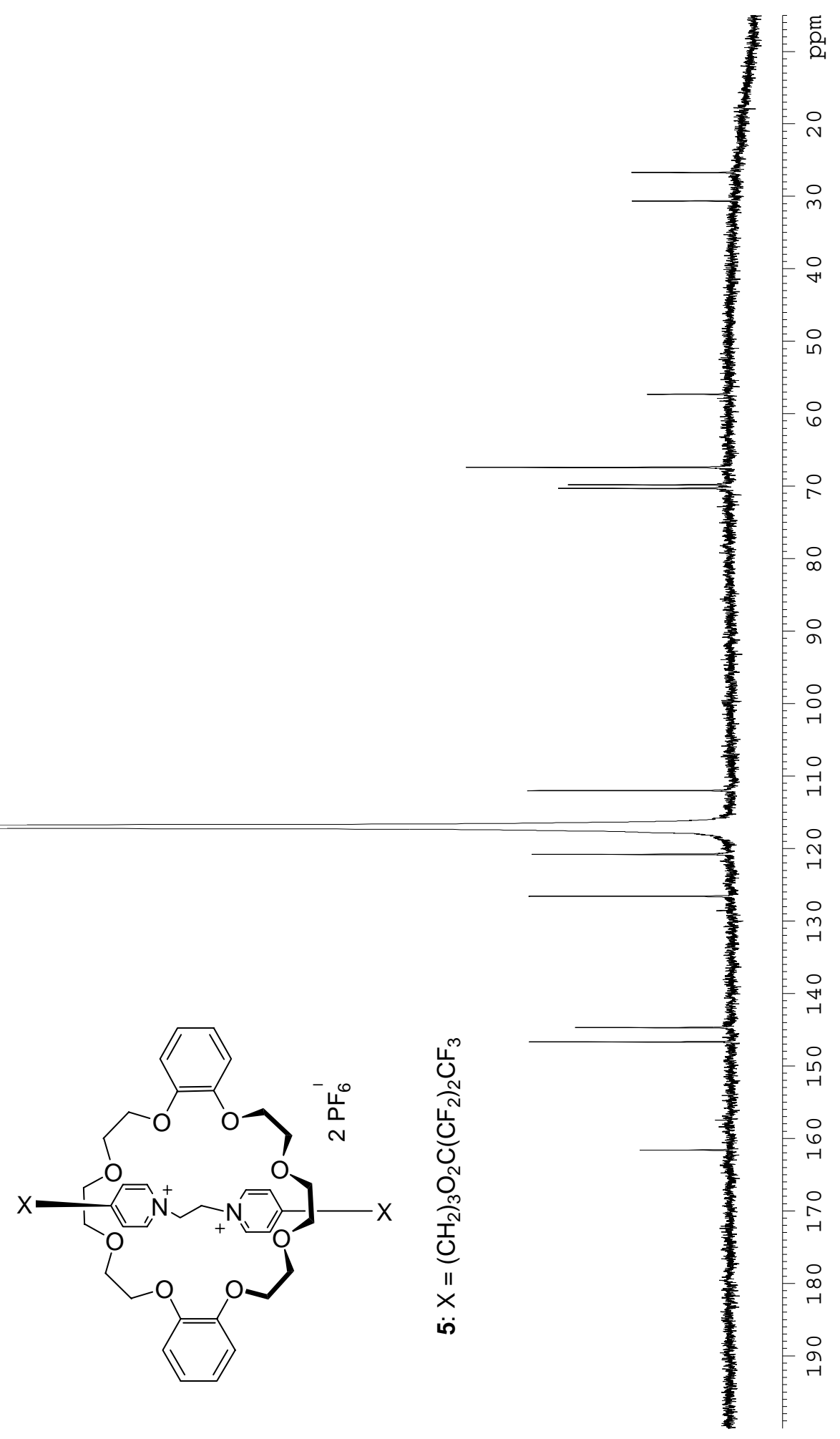


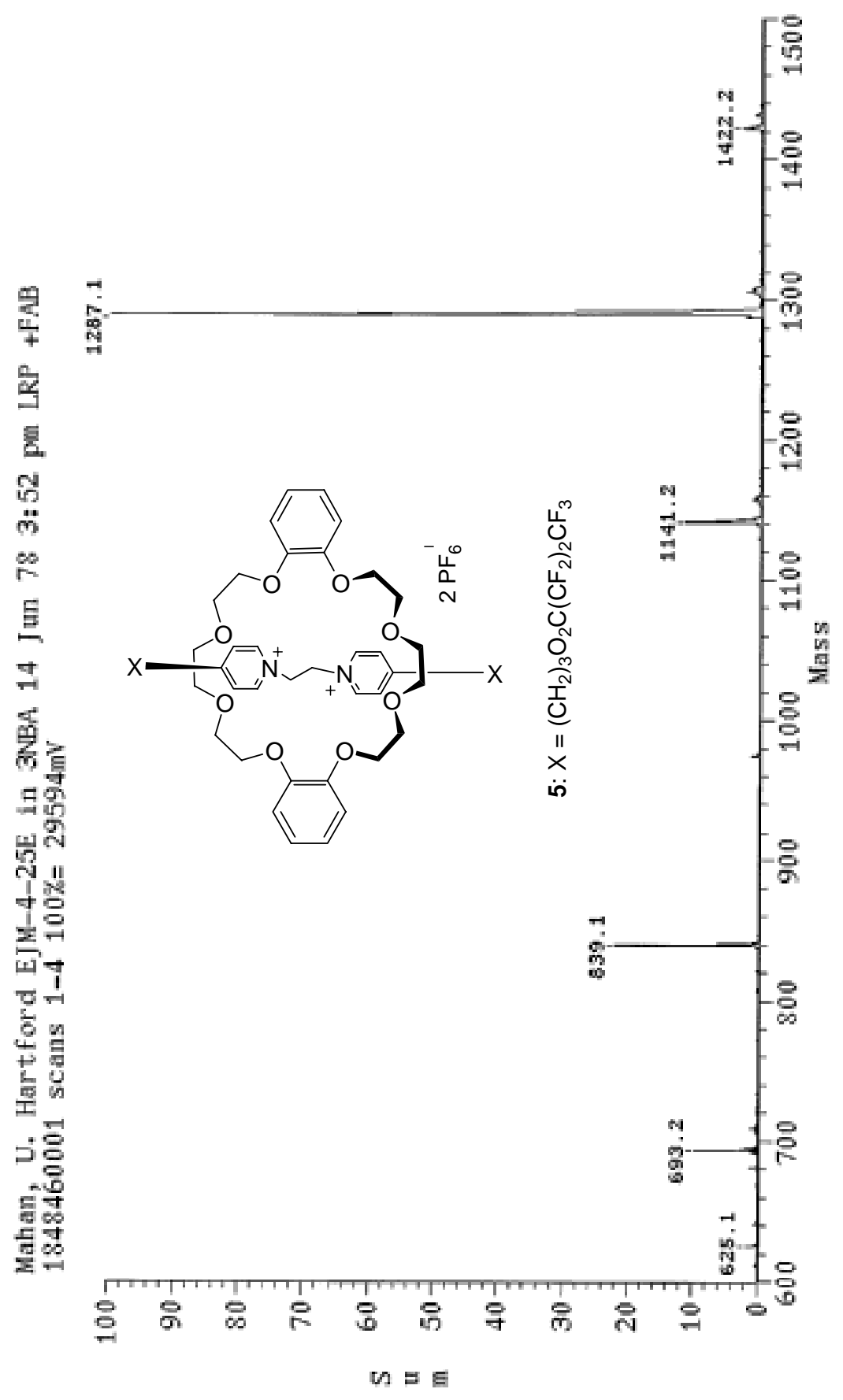




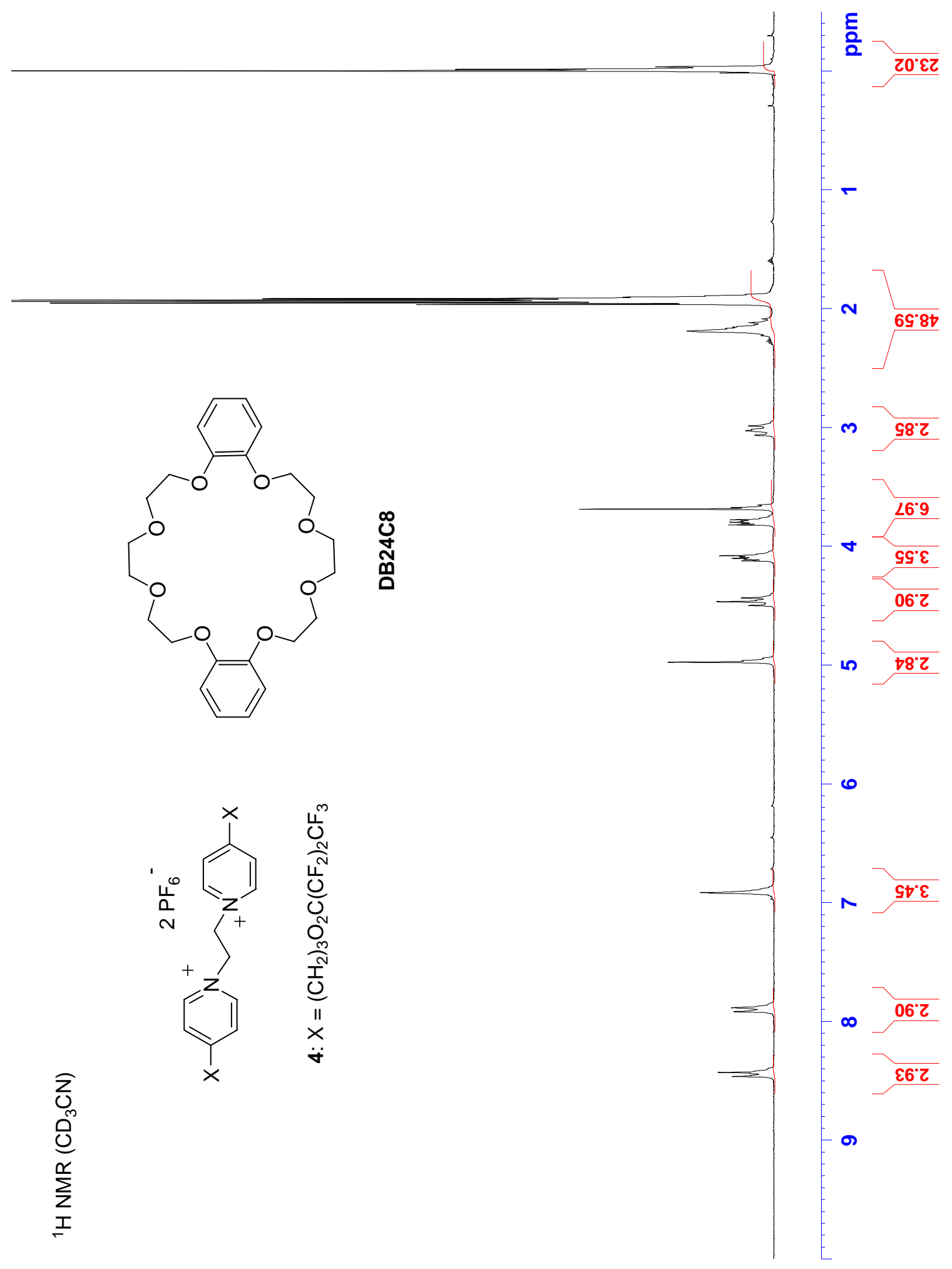




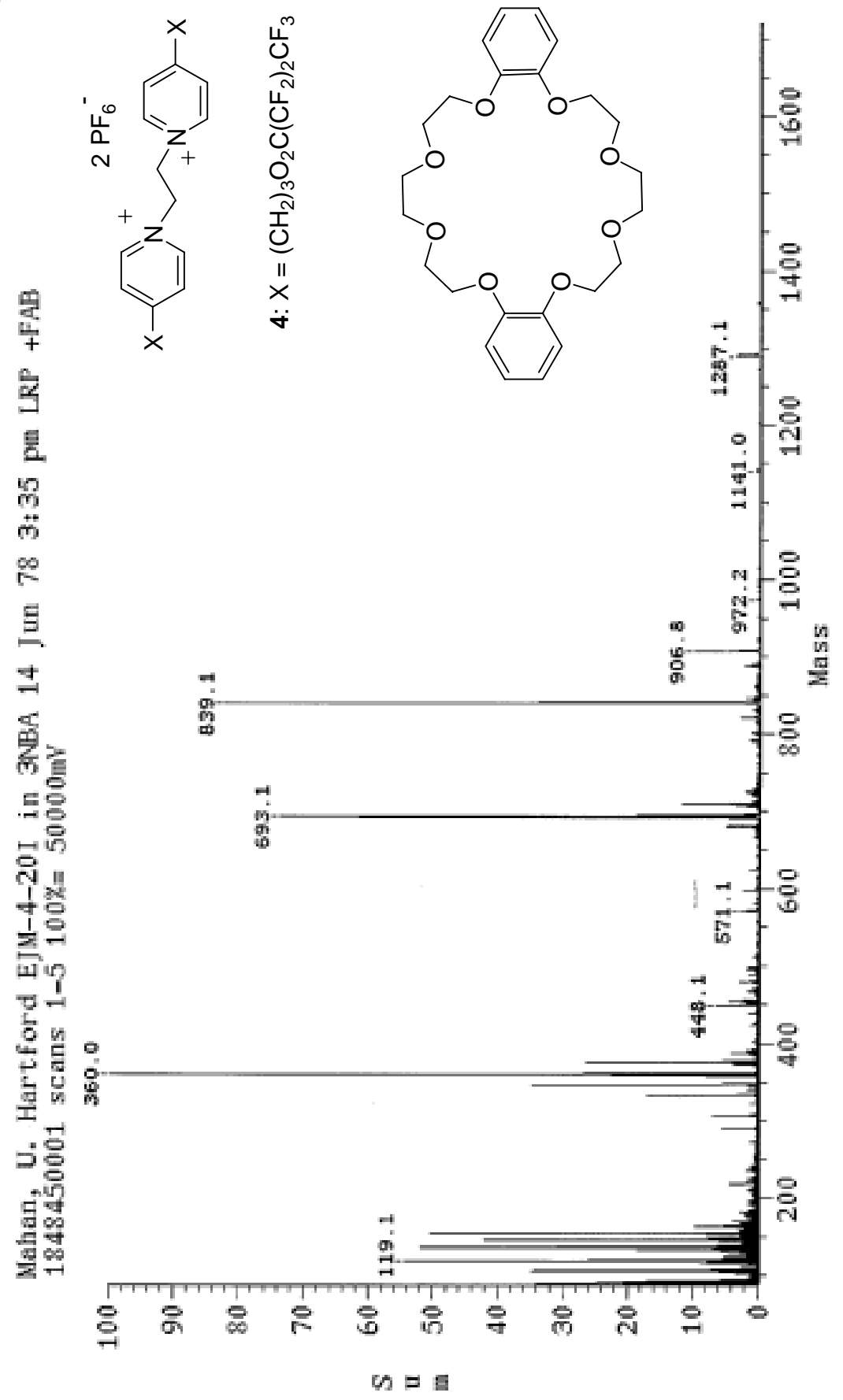




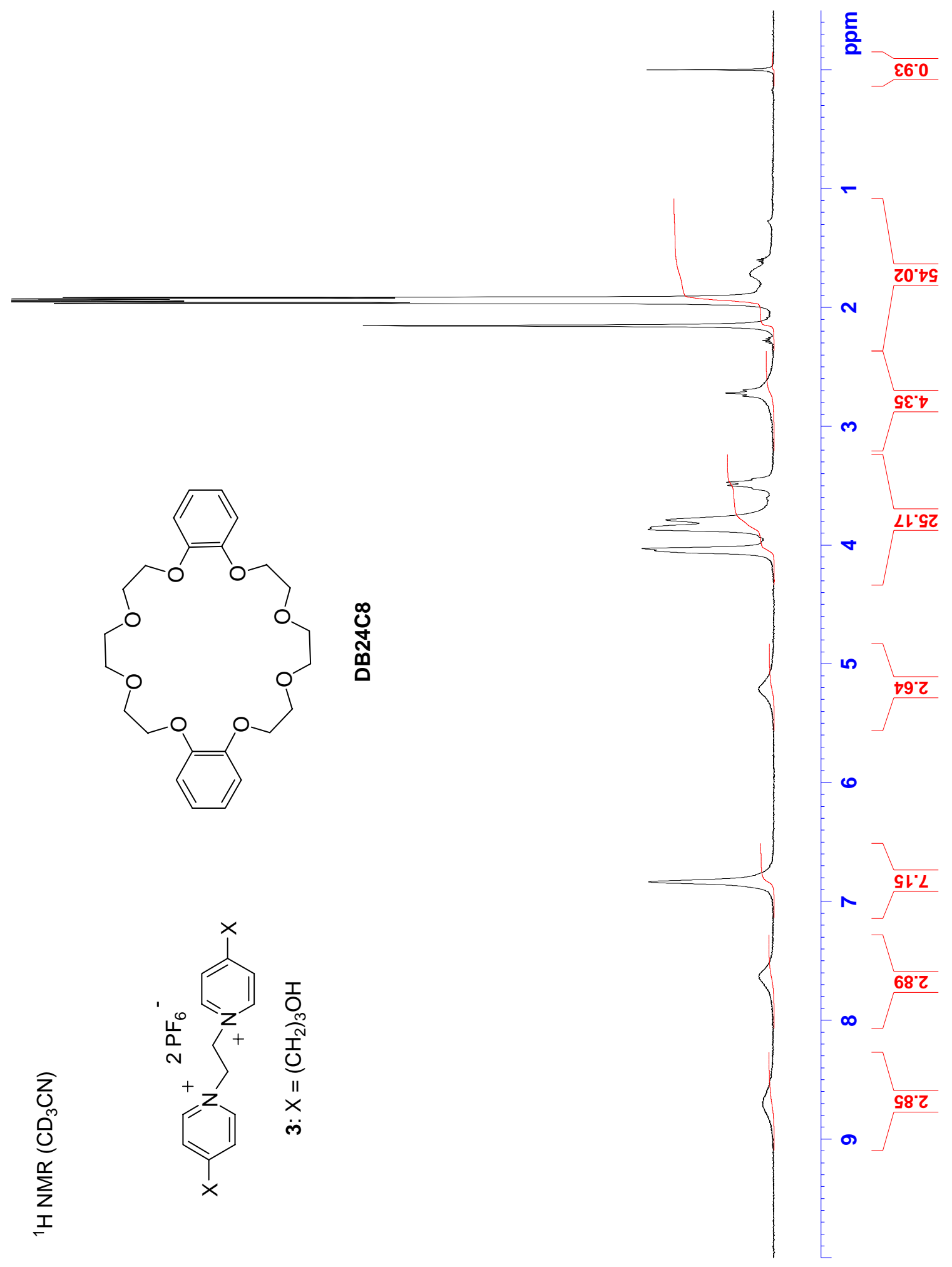




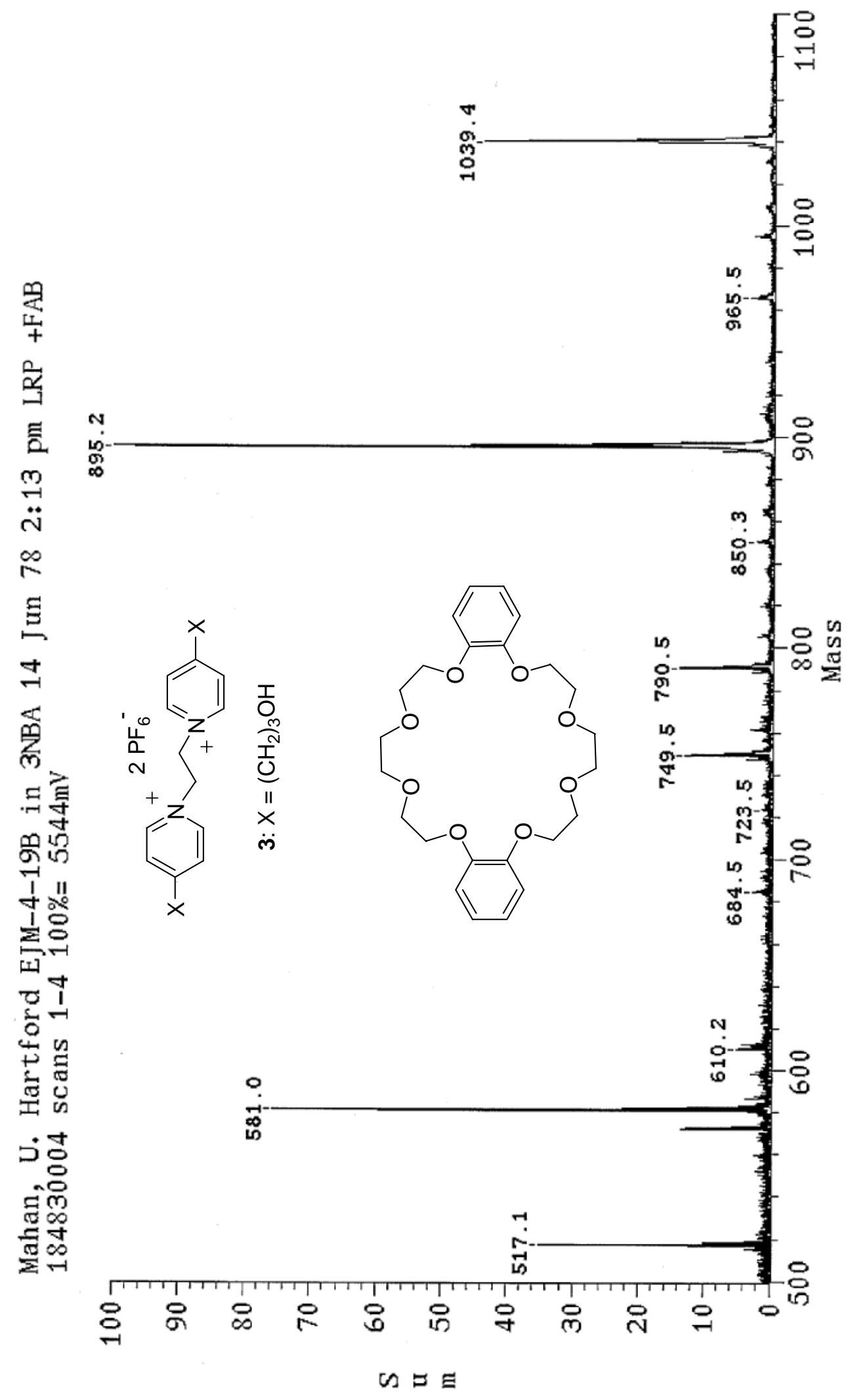

